Conference Paper

\title{
Implementation of Green Accounting Based on University Social Responsibility
}

\author{
Dwi Suhartini, Tituk Diah Widajantie, Astrini Aning Widoretno*, Fajar Nugroho \\ Accounting, Economics and Business Faculty, Universitas Pembangunan Nasional “Veteran" Jawa Timur, \\ Indonesia
}

*Corresponding author:

E-mail:

astrini.widoretno.ak@upnjatim.ac.id

\begin{abstract}
University is a contributor to waste from its operational impacts, for this reason, it is obliged to report its activities to protect the environment. This is in line with the achievement of the Sustainable Development Goals in 2030, namely ending poverty, reducing inequality, and protecting the environment. For that, it is very appropriate if all universities in Indonesia implement University social responsibility (USR). The purpose of this study was to examine more deeply the implementation of USR using a literature review approach. This study makes a real contribution in making public policies about the importance of implementing USR in University. For this reason, the research question is the extent to which USR based green accounting is implemented which includes environmental awareness, environmental involvement, environmental reporting, and environmental auditing. The results of the study have proven that the implementation of USR-based green accounting has been carried out by tertiary institutions properly, in real-life lectures (KKN) activities such as conducting training for the community on organic and nonorganic waste management and empowering communities around campus. However, the environmental report has not been published properly even though the report has been made. Also, the implementation of environmental audits has not been carried out optimally.
\end{abstract}

Keywords: Environmental awareness, environmental involvement, environmental reporting, environmental auditing, green accounting.

\section{Introduction}

The implementation of University Social Responsibility (USR) is a concrete form of higher education in responding to the Minister of Research and Technology Instruction number 1 / M-Ins / 2019 concerning the prohibition of using single-use plastic drinking water and/or plastic bags within the ministry of research, technology, and higher education. other than that, Law no. 23 of 1997 concerning environmental management. This law regulates the obligations of every person who undertakes or carries out activities to maintain, manage, and provide true and accurate information about the environment.

University is one of the entities that produce waste from the impact of its operations, therefore, it is obliged to report these activities to protect the environment. The waste management is an important part of the sustainability value chain. This is in line with the achievement of the Sustainable Development Goals in 2030, namely ending poverty, reducing inequality, and protecting the environment. for that, it is very appropriate if all universities in Indonesia implement USR.

University Social Responsibility (USR) or university social responsibility is part of the concept of Corporate Social Responsibility (CSR). As for CSR, it aims to add value to an entity with 3 P's, namely responsibility for profit, people, and the planet, while USR is implemented by universities

\section{How to cite:}

Suhartini, D., Widajantie, T. D., Widoretno, A. A., \& Nugroho, F. (2021). Implementation of green accounting based on university social responsibility. $5^{\text {th }}$ International Seminar of Research Month 2020. NST Proceedings. pages 180-183. doi: 10.11594/ nstp.2021.0927 
to contribute to added value to society and its environment. Wijaya and Krismiyati's research (2016) states that USR activities in higher education are more often known as community service activities, more specifically for the university's stakeholders. based on Law no. 40 of 2007 concerning corporate social responsibility, especially Article 74 obliges business people to carry out social responsibility. Thus, Chen et al. (2015) explained that USR can be considered as a university philosophy as an ethical approach to developing and engaging with local and global communities in maintaining the social, ecological, environmental, technical, and economic development environment.

University has an important role in applying and shaping the development of science and technology, enriching learning resources, and/or for learning and maturing the academic community. in the world of education, there is a learning process to produce changes in behavior to shape the human character and have value in society. Higher education is a formal education institution where students add and develop abilities to face an increasingly competitive world of work. Therefore, higher education has a very important role in developing individual abilities to be more insightful in science, technology, and the formation of good character.

Community service activities are part of the implementation of USR which has activities to help the surrounding environment or society without strings attached in any form. Therefore, as stated by Devoniz and that community service activities are generally conceptualized by universities in Indonesia, the aim is to contribute real thoughts for the progress and development of the welfare of the Indonesian nation. USR is carried out in the form of community service at the University which is often referred to as Real Work Lecture (KKN) activities. KKN can be in the form of providing training to the community on processing organic and non-organic waste, conducting nature conservation, and providing assistance in the management of village funds.

The application of USR reflects the impact of an organization's activities on its environment and the form of organizational responsibility must be informed as a report to mitigate the impact resulting from its operational activities. accounting as a discipline that is useful for providing information as a form of transparency of the organization must also adapt to changes in demand for information needed. accounting that is more specifically concerned with and applies environmental cost calculations into USR practices is called Environmental Accounting or better known as Green Accounting. There are stages of Green Accounting based on University Social Responsibility (USR), which include environmental awareness, environmental involvement, environmental reporting, environmental auditing.

The purpose of this study was to examine more deeply the implementation of USR using a literature review approach. This research makes a real contribution in making public policies about the importance of implementing USR in universities. For this reason, the research question is the extent to which USR-based green accounting is implemented which includes environmental awareness, environmental involvement, environmental reporting, and environmental auditing. This study will present a literature review to analyze the factors forming green accounting based on university social responsibility (USR) so that it can be seen to what extent the factors that make up green accounting based on university social responsibility (USR) with various literature approaches.

\section{Material and Methods}

This study uses a literature review approach to analyze the factors forming green accounting based on university social responsibility (USR) by examining several journals and books related to university social responsibility. 


\section{Results and Discussion}

Based on studies conducted from various journals that raise the topic of USR, the implementation of USR-based green accounting has been implemented very well on the factors of environmental awareness and environmental involvement. However, the implementation of factors related to environmental reporting and environmental auditing factors has not been implemented optimally.

The implementation of care and involvement in the environment is manifested in the activities of the Real Work Lecture (KKN) program. Each tertiary institution has a KKN program filled with community empowerment activities, such as providing training to the community to process organic waste and recycle plastic waste. Suhardiyah (2019) explain that the form of environmental accounting that is most expected by the role of universities in the KKN-PPMKKN Program, Improvement of Campus Public Facilities, Giving Scholarships, Involving Social Service Activities on Campus. Likewise, Subagyo (2014) prove that the form of social responsibility is formally implied in the third Tridharma of Higher Education, namely community service. Likewise, Rumambi and Lintong (2012) state that social responsibility activities include social and environmental aspects which are carried out regularly every year, one of which is through the realization of the third tridharma, namely community service. Supported also by Wijaya and Krismiyati (2016) that USR activities are identical to community service activities. However, it is different from what Chen et al. (2015) stated that the implementation of USR is considered a future need, but now what is important is to improve academic services.

The implementation of USR on environmental reporting factors and environmental auditing factors has not been implemented optimally. This is found in the results of Ignastia's research (2017) that however, it does not have good environmental reporting, and aspects of environmental auditing are still in the process of being improved. The stated that the publication of environmental cost reports has not been implemented properly as well as environmental audits. Likewise, Lubis et al (2018) stated that the publication of environmental cost reports has not been implemented properly as well as environmental audits. Also states that universities have not conducted environmental audits and there are no reports, this is related to the fact that SPI activities do not handle environmental audits. Ignastia (2017) states that Brawijaya University has made environmental reports but has not been published yet, while environmental audits are in the process of improvement.

\section{Conclusion}

The results of the study have proven that the implementation of USR-based green accounting has been carried out by higher education institutions well in terms of environmental awareness and environmental involvement. The activities are applied in real-life lectures (KKN) activities such as conducting training for the community on organic and non-organic waste processing and empowering communities around the campus. However, the environmental report has not been published properly even though the report has been made. Also, the implementation of environmental audits has not been carried out optimally.

\section{Acknowledgment}

The first author would like to express her thank you of gratitude to all the team members as well as Fajar Nugroho (magister of accounting's student) who have worked so well to make this research and article happened within the limited time frame and during this pandemic.

\section{References}

Chen, S. H., Nasongkhla, J., \& Donaldson, J. A. (2015). University Social Responsibility (USR): Identifying an ethical foundation within higher education institutions. Turkish Online Journal of Educational Technology-TOJET, 14(4), 165-172. 
Ignastia, C. D. (2017). Implementasi green accounting berbasis University Social Responsibility (USR) di Universitas Brawijaya. Jurnal Ilmiah Mahasiswa FEB, 5(2), 110-120.

Lubis, N. G., Wahyuni, E. D., \& Zubaidah, S. (2018). Analisis pengungkapan university social responsibility di UIN Maulana Malik Ibrahim Malang. Jurnal Akademi Akuntansi (JAA), 1(1), 115-125.

Subagyo, S. (2014). Implementasi tanggung jawab sosial perguruan tinggi dan dampaknya terhadap citra kampus di Universitas Nusantara PGRI Kediri. Nusantara of Research, 1(02), 155329.

Suhardiyah, M. (2019). Implementation of environmental accounting in higher education solutions to improve the college' s role in the implementation of corporate social responsibility. In IOP Conference Series: Earth and Environmental Science, 245(1), 012027.

Wijaya, L. S., \& Krismiyati, K. (2016). Pertanggungjawaban sosial Universitas: Implementasi model cycle relations. Jurnal Ekonomi dan Bisnis, 19(2), 195-210. 